\title{
Efficacy of Some Fungicides and Bio-control Agents against Tuber Rot (Fusarium oxysporum) of Kalazeera (Bunium persicum)
}

\author{
Sabiya Bashir*, Mohammad Najeeb Mughal, Seeratun Nissa, Zahoor A. Dar, S.A. \\ Hakeem, Shabeena Majeed, Shaheena Nagoo and Sabeena Naseer
}
Sher-i-Kashmir University of Agricultural Sciences and Technology of Kashmir, Shalimar, Srinagar-190025, India

*Corresponding author

\begin{tabular}{|c|}
\hline Keywords \\
\hline $\begin{array}{l}\text { Bio-control, Kala } \\
\text { zeera, Fusarium } \\
\text { oxysporum, In-vitro, } \\
\text { Non- systemic } \\
\text { fungicides, } \\
\text { Systemic fungicides }\end{array}$ \\
\hline Article Info \\
\hline $\begin{array}{l}\text { Accepted: } \\
26 \text { June } 2018 \\
\text { Available Online: } \\
\text { 10 July } 2018\end{array}$ \\
\hline
\end{tabular}

\section{Introduction}

Kala zeera (Bunium persicum) also black cumin is an economically important culinary crop that is cultivated for its seed pods and its tuber like roots. In India, kalazeera is cultivated in high altitude regions of Himachal growth.
Six non-systemic fungicides viz., captan $50 \mathrm{WP}$, copper oxychloride $50 \mathrm{WP}$, dodine 65 $\mathrm{WP}$, mancozeb75 WP, propineb $70 \mathrm{WP}$ and zineb $80 \mathrm{WP}$ and five systemic fungicides viz., bitertanol $25 \mathrm{WP}$, carbendazim $50 \mathrm{WP}$, difenconozole $25 \mathrm{EC}$, hexaconozole 5EC, and myclobutanil $10 \mathrm{WP}$ were evaluated against tuber rot of kalazeera caused by Fusarium solani. The in-vitro evaluation of non-systemic fungicides through poisoned food technique at five different concentrations viz., 50, 100, 250, 500 and 1000 ppm on active ingredient basis (a.i) indicated that dodine was most effective exhibiting mean mycelial growth inhibition of 82.27 per cent followed by captan (67.99\%). Copper oxychloride proved least effective and resulted in only 29.81 per cent mean inhibition of mycelial growth. Among the systemic fungicides, evaluated at concentrations viz., 25, 50, 100, 200 and 500ppm on active ingredient basis (a.i), carbendazim proved most effective exhibiting mean mycelial growth inhibition of 90.23 per cent followed by hexaconozole and bitertanol with 71.24 and 64.56 per cent mean mycelial growth inhibition, respectively. Myclobutanil proved least effective and resulted in only 52.76 per cent mean inhibition of mycelial growth. Five strains of Trichoderma viride strains designated as Tv-1, Tv-2 Tv-3, Tv-4, Tv-5 and two strain of Trichoderma harzianum designated as Th-1 and Th- 2 were also evaluated against tuber rot pathogen. Among the bio-control agents Tv-4 was most efficacious and resulted in 48.20 mean mycelial growth inhibition followed by Tv-2 with 47.06 per cent mean inhibition of mycelial growth. Trichodermaviride-5 (Tv-5) proved least efficious and resulted in only 26.40 per cent mean inhibition of mean mycelial

\section{A B S T R A C T}


Since the crop usually grows wild in scattered pockets, the yields are lower at $129 \mathrm{~kg} / \mathrm{ha}$ (J\&K) and $179 \mathrm{~kg} / \mathrm{ha}$ (H.P), as compared to $350-400 \mathrm{~kg} / \mathrm{ha}$ in the case of caraway (Panwar, 1992). The Yield of kalazeera is dwindling year after year due to the diseases, insect pest, inadequate planting density, high weeds incidence lack of nutritional processing techniques and poor crop management practices (Anonymous 2004). Kala zeera is prone to the number of diseases, including both fungal and bacterial. Under temperate conditions of Kashmir kalazeera is attacked by Alternaria leaf spot and Cercospora leaf spot pathogens but tuber rot caused by Fusarium oxysporum is most important disease of kalazeera which causes drying of foliage and rotting of tubers. White fungal mycelia can be observed on the tubers at the late stages of disease development. Incidence of this disease has been reported to vary from 80 to 90 per cent and yield loss of 50 to 60 per cent has been reported (Badri et al., 2013). The use of fungicides and biological methods are most effective andreliable methods of controlling the disease. Fungicides with novel chemistry are being introduced and evaluated before their application can be recommended to farmers. Therefore, laboratory evaluation of the fungicides is of paramount importance. There is constant need to watch and evaluate new fungicides along with some non-chemical method of controlling the wilt disease (Patel, 1998). Therefore, present studies were carried out to evaluate non- systemic and systemic fungicides and some bio-control agents against the disease and the results are presented herein.

\section{Materials and Methods}

Sixnon-systemic fungicides viz., captan 50WP, copper oxychloride $50 \mathrm{WP}$, dodine 65 $\mathrm{WP}$, mancozeb $75 \mathrm{WP}$, propineb $70 \mathrm{WP}$ and zineb 80WP and five systemic fungicides viz., bitertanol 25WP, carbendazim 50 WP, difenconazole 25EC, hexaconozole 5EC, and myclobutanil 10WP were evaluated in-vitro on active ingredient (a.i) basis against tuber rot of kalazeera caused by Fusarium solanit hrough poisoned food technique (Carpenter, 1942) using potato dextrose agar medium. The non-systemic fungicides were evaluated at 50 , 100, 250, 500 and $1000 \mathrm{ppm}$ and systemic fungicides at 50, 100, 200, 400 and $500 \mathrm{ppm}$. The required concentrations of fungicides were prepared by adding appropriate amount of fungicides to sterilized molten PDA medium in conical flasks. Thirty millilitre of such amended PDA was aseptically poured in sterilized Petri plates. A $5 \mathrm{~mm}$ diameter mycelial disc of FOC was aseptically placed in the centre of each Petri plate. Petri plates containing PDA media amended with equal amount of sterilized distilled water and inoculated with mycelial disc of Fusarium oxysporum (5 mm diameter) served as check. Each treatment was replicated thrice and incubated at $28 \pm 2{ }^{\circ} \mathrm{C}$ for $48 \mathrm{hrs}$. The comparative efficacy of fungicides was calculated as per cent inhibition of mycelial growth of the test fungus in each treatment as compared to check by the following formula:

Per cent mycelial growth inhibition $=$

$$
\frac{\mathrm{C}-\mathrm{T}}{\mathrm{C}} \times 100
$$

\section{Where}

$\mathrm{C}=$ Radial mycelial growth $(\mathrm{mm})$ in check

$\mathrm{T}=$ Radial mycelial growth in the treatment (mm)

\section{In-vitro evaluation of bio-control agents}

The biological control agents were isolated from soils of different parts of Kashmir and designated as Trichoderma viridi 1 , Trichoderma viridi 2, Trichoderma viridi 3, Trichoderma viridi 4 and Trichoderma viridi 
5, and Trichoderma harzianum 1 and Trichoderma harzianum 2. The pure culture was multiplied in the test tubes slants. Agar slants of these cultures were placed in refrigerator at $4^{0} \mathrm{C}$. Mycelial discs $(5 \mathrm{~mm}$ diameter)of bio-control agent and the pathogen were simultaneously inoculated at the opposite ends of the Petriplates, containing about $20 \mathrm{ml}$ of PDA medium. Three Petri plates were used for each biological control agent and the same number was kept as control. Inoculated Petri plates were incubated at $25^{ \pm} 2^{\circ} \mathrm{C}$ for $7-10$ days. The data regarding per cent inhibition of mycelial growth were calculated by standard method.

\section{Results and Discussion}

Persual of data (Table 1) indicate that among non-systemic fungicides, dodine was most effective exhibiting highest mean mycelial growth inhibition of 82.27per cent followed by captan $(67.92 \%)$ while mancozeb, zineb and antracol resulted in mean inhibition of mycelial growth of 58.98, 46.86 and 46.14 per cent, respectively. Copper oxychloride proved least effective among non-systemic fungicides and resulted in lowest mean mycelial inhibition of 29.81per cent only. In general, the efficacy of fungicides increased with increase in their concentrations. At the lowest concentration of $50 \mathrm{ppm}$, dodine was most effective causing 61.66 per cent mean mycelial inhibition followed by captan (44.40) while copper oxychloride was least efficacious $(25.90 \%)$. Similar trend was observed with increase in concentration and at the highest concentration $(1000 \mathrm{ppm})$ dodine completely inhibited the mycelial growth of the pathogen followed by captan which caused 81.43 per cent mean mycelial inhibition and copper oxychloride resulted in lowest mean mycelial inhibition of only 38.20 per cent.

Among the five systemic fungicides (Table 2), carbendazim proved most effective exhibiting highest mean mycelial growth inhibition of 90.23per cent followed by hexaconozole and bitertanol with 71.24 and 64.56 per cent mean mycelial growth inhibition, respectively. Difenoconazole resulted in mean mycelia growth inhibition of 60.84per cent, while myclobutanil proved least effective among the systemic fungicides and resulted in lowest mean mycelial growth inhibition of only 52.76per cent mean.

In general, the efficacy of fungicides increased with increase in their concentrations. At the lowest concentration of $50 \mathrm{ppm}$, carbendazim was most effective causing 82.00 per cent mean mycelial inhibition followed by hexaconazole $(53.80 \%)$ while myclobutanil was least efficacious (43.53\%).

Similar trend was observed with increase in concentration of fungicides and efficiency of fungicides increased with increase in their concentrations. Carbendazim resulted in 100 per cent inhibition at 200 and $500 \mathrm{ppm}$ concentrations. However, no other fungicide could cause complete inhibition of mycelial growth of the pathogen at $200 \mathrm{ppm}$ concentration. At the highest concentration $(500 \mathrm{ppm})$ hexaconazole also completely inhibited the mycelial growth (100\% mycelial growth inhibition) of the pathogen followed by difenoconazole and bitertenol which caused 74.30 and 66.70 per cent mean mycelial inhibition, respectively. Even at the highest concentration (500ppm), myclobutanil resulted in lowest mean mycelial growth inhibition of only61.50 per cent.

The in-vitro evaluation of bio-control agents revealed that $\mathrm{Tv}-4$ and $\mathrm{Tv}-2$ was most efficacious and resulted in 48.20 and 47.06 per cent mean mycelial inhibition followed by Tv1 with 45.93 per cent mean inhibition of mycelial growth. Trichoderma viride-5 (Tv-5) proved least efficious and resulted in only 26.40 per cent mean inhibition of mycelial growth (Table 3 ). 
Table.1 In-vitro evaluation of non-systemic fungicides against Fusarium oxysporum causing tuber rot of kalazeera

\begin{tabular}{|c|c|c|c|c|c|c|}
\hline \multirow[t]{2}{*}{ Fungicides } & \multicolumn{6}{|c|}{ Per cent inhibition of radial mycelial growth at concentration (ppm) } \\
\hline & 50 & 100 & 250 & 500 & 1000 & Mean \\
\hline Captan 50WP & $\begin{array}{l}44.40 \\
(41.77)\end{array}$ & $\begin{array}{l}70.06 \\
(56.84)\end{array}$ & $\begin{array}{l}71.86 \\
(57.98)\end{array}$ & $\begin{array}{l}72.20 \\
(58.20)\end{array}$ & $\begin{array}{l}81.43 \\
(64.48)\end{array}$ & 67.99 \\
\hline Mancozeb 75 WP & $\begin{array}{l}44.03 \\
(41.03)\end{array}$ & $\begin{array}{l}53.26 \\
(46.87)\end{array}$ & $\begin{array}{l}53.26 \\
(46.87)\end{array}$ & $\begin{array}{l}64.16 \\
(53.23)\end{array}$ & $\begin{array}{l}80.20 \\
(63.62)\end{array}$ & 58.98 \\
\hline $\begin{array}{l}\text { Copper oxychloride } 50 \\
\text { WP }\end{array}$ & $\begin{array}{l}25.90 \\
(30.59)\end{array}$ & $\begin{array}{l}28.33 \\
(32.11)\end{array}$ & $\begin{array}{l}27.06 \\
(31.26)\end{array}$ & $\begin{array}{l}29.56 \\
(32.93)\end{array}$ & $\begin{array}{l}38.20 \\
(38.17)\end{array}$ & 29.81 \\
\hline Antracol $70 \mathrm{WP}$ & $\begin{array}{l}37.00 \\
(37.46)\end{array}$ & $\begin{array}{l}38.23 \\
(38.23)\end{array}$ & $\begin{array}{l}41.96 \\
(40.37)\end{array}$ & $\begin{array}{l}50.60 \\
(45.34)\end{array}$ & $\begin{array}{l}62.90 \\
(52.51)\end{array}$ & 46.14 \\
\hline Dodine $65 \mathrm{WP}$ & $\begin{array}{l}61.66 \\
(51.75)\end{array}$ & $\begin{array}{l}75.33 \\
(60.17)\end{array}$ & $\begin{array}{l}81.43 \\
(64.48)\end{array}$ & $\begin{array}{l}92.96 \\
(74.67)\end{array}$ & $\begin{array}{l}100.00 \\
(90.00)\end{array}$ & 82.27 \\
\hline Zineb & $\begin{array}{l}35.76 \\
(36.76)\end{array}$ & $\begin{array}{l}43.13 \\
(41.05)\end{array}$ & $\begin{array}{l}43.16 \\
(41.06)\end{array}$ & $\begin{array}{l}51.83 \\
(46.04)\end{array}$ & $\begin{array}{l}60.43 \\
(51.02)\end{array}$ & 46.86 \\
\hline Mean & 41.45 & 51.18 & 53.12 & 60.22 & 70.52 & \\
\hline $\begin{array}{l}\text { CD }(P=0.05) \\
\text { Non-systemic fungicide } \\
\text { Concentration } \\
\text { Fungicide } \times \text { Concentration }\end{array}$ & $\begin{array}{l}=(2.1) \\
=(1.9) \\
=(4.70)\end{array}$ & & & & & \\
\hline
\end{tabular}

*Figures within parentheses are arc sign transformed values

Table.2 In-vitro evaluation of systemic fungicides against Fusarium oxysporum causing tuber rot of kalazeera

\begin{tabular}{|c|c|c|c|c|c|c|}
\hline \multirow[t]{2}{*}{ Fungicides } & \multicolumn{6}{|c|}{ Per cent inhibition of radial mycelial growth at concentration } \\
\hline & 25 & 50 & 100 & 200 & 500 & Mean \\
\hline $\begin{array}{l}\text { Hexaconozole } \\
5 \mathrm{EC}\end{array}$ & $53.80(41.17)$ & $\begin{array}{l}61.50 \\
(51.64)\end{array}$ & $\begin{array}{l}66.60 \\
(54.69)\end{array}$ & $\begin{array}{l}74.30 \\
(59.53)\end{array}$ & $\begin{array}{l}100.00 \\
(90.00)\end{array}$ & 71.24 \\
\hline $\begin{array}{l}\text { Myclobutanil } \\
10 \text { WP }\end{array}$ & $43.53(41.28)$ & $\begin{array}{l}51.23 \\
(45.70)\end{array}$ & $\begin{array}{l}51.20 \\
(45.68)\end{array}$ & $\begin{array}{l}56.33 \\
(48.63)\end{array}$ & $\begin{array}{l}61.50 \\
(51.64)\end{array}$ & 52.76 \\
\hline $\begin{array}{l}\text { Carbendazim } \\
50 \mathrm{WP}\end{array}$ & $82.00(64.89)$ & $\begin{array}{l}84.56 \\
(66.86)\end{array}$ & $\begin{array}{l}84.60 \\
(66.89)\end{array}$ & $\begin{array}{l}100.00 \\
(90.00)\end{array}$ & $\begin{array}{l}100.00 \\
(90.00)\end{array}$ & 90.23 \\
\hline $\begin{array}{l}\text { Difenconazole } \\
25 \mathrm{EC}\end{array}$ & $51.23(45.70)$ & $\begin{array}{l}64.03 \\
(53.14)\end{array}$ & $\begin{array}{l}64.06 \\
(53.16)\end{array}$ & $\begin{array}{l}69.16 \\
(56.26)\end{array}$ & $\begin{array}{l}74.30 \\
(59.53)\end{array}$ & 60.84 \\
\hline $\begin{array}{l}\text { Bitertanol } \\
25 \mathrm{WP}\end{array}$ & $48.66(44.23)$ & $\begin{array}{l}56.33 \\
(48.63)\end{array}$ & $\begin{array}{l}64.10 \\
(53.19)\end{array}$ & $\begin{array}{l}66.63 \\
(54.71)\end{array}$ & $\begin{array}{l}66.70 \\
(54.74)\end{array}$ & 64.56 \\
\hline Mean & 55.84 & 63.53 & 66. 11 & 73.28 & 80.50 & \\
\hline $\begin{array}{l}\mathrm{CD}(\mathrm{P}=0.05) \\
\text { Fungicide } \\
\text { Concentration } \\
\text { Fungicide } \times \text { Conce }\end{array}$ & $\begin{aligned} & =(1 . \\
& =(125 \\
\text { tration } & =(2.33\end{aligned}$ & & & & & \\
\hline
\end{tabular}

Figures within parentheses are arc sign transformed values 
Table.3 In-vitro evaluation of bio-control agents against Fusarium oxysporum causing tuber rot of Kala zeera

\begin{tabular}{|l|c|}
\hline Bio-control agents & $\begin{array}{c}\text { Per cent } \\
\text { inhibition in radial mycelial growth } \\
\text { of }\end{array}$ \\
\hline Trichoderma viridi-1 & 45.93 \\
(Tv-1) & $(42.66)$ \\
\hline Trichoderma viridi-2 & 47.06 \\
(Tv-2) & $(43.31)$ \\
\hline Trichoderma viridi-3 & 37.70 \\
(Tv-3) & $(34.87)$ \\
\hline Trichoderma viridi-4 & 48.20 \\
(Tv-4) & $(43.96)$ \\
\hline Trichoderma viridi-5 & 26.40 \\
(Tv-5) & $(30.87)$ \\
\hline Trichoderma harzianum-1 & 36.73 \\
(Th-1) & $(37.30)$ \\
\hline Trichoderma harzianum $\mathbf{- 2}$ & 39.60 \\
(Th-2) & $(38.99)$ \\
\hline CD $(\mathbf{P = 0 . 0 5 )} \quad(\mathbf{2 . 0 1 )}$ & \\
\hline
\end{tabular}

Figures within parentheses are arc sign transformed values

Evaluation of fungicides and bio-control agents in-vitro is indispensible for determining their efficacies before they are finally take to field for evaluation. In-vitro evaluation helps in selecting the best fungicide(s) and bio-control agent(s) among the array of fungicides and bio-control agents. In-vitro evaluation also determines the best concentration at which the fungicide(s) is/are most effective. Evaluation of fungicides in field without in-vitro evaluation at different concentrations is practically not feasible and would include huge land, labour and costs. Kala zeera is a niche crop of Kashmir and not much work has been done on diseases of this important cash crop. Our results are in conformity with those reported by Aghnoom et al, (1999), Aghnoom et al., (2002), Ghasolia and Jain (2004), Khan et al., (2012). Generally, all the treatments checked the activities of the pathogen (Fusarium oxysporum) and consequently promote the growth of Kala zeera. In the present study, among biological control agents, Trichoderma viridi proved most effective and these findings were completely in agreement with Saikia et al., 2003; Ghasolia and Jain, 2004 and Postma et al., 2003.

\section{References}

Aghnoom, R., M. Falahati-Rastegar, Jafarpour,B. 1999.Comparison of chemical and biological control of cumin wilt (Fusarium oxysporum f. sp. cumini) in laboratory and green house conditions. Iranian Journal of Agricultural Science 30(3), 619-630.

Aghnoom, R., M. Falahati-Rastegar, B. Jafarpour, 2002, Comparison of chemical and biological control of cumin wilt (Fusarium oxysporum $\mathrm{f}$. sp. cumini) in laboratory and green house conditions. Iranian Journal of Agricultural Sciences. 30(3): 619-630. 
Anonymous. 2004.Progress report of NATP subproject on selection of improved genotypes and development of sustainable production systems for kalazeera (B. persicum Bioss.). SKUAST-K p. 49.

Badri, Z. A.,Rather, M. A., Parmeet Singh.2013.Evaluation of fungitoxicants against Fusariumsolanicausing tuber rot disease of kalazeera [Bunium persicum( Bioss) Fedtsch.]. Environment and Ecology 31(4): 1851-1855.

Carpenter, J.B., 1942.A toximetric study of some eradicant fungicides. Phytopathology 32: 845.

Ghasolia, R. P., S. C. Jain, 2004, Evaluation of fungicides, bio-agents, phytoextracts and physical seed treatment against Fusarium oxysporum f. sp. Cumini causing wilt in cumin. Journal of Mycology Plant Pathology. 34(2): 334-336.

Khan, H.S.I., M. Saifulla, A.S.N. Nawaz, P.R. Somashekharappa and R. Razvi. 2012. Efficacy of fungicides and bio-control agents against Fusarium oxysporum f. sp. ciceris causing wilt of chickpea. Journal of Environment and Ecology 3: 570-572.

Panwar K. Kala zeera: A low volume, high price crop for dry temperate hills. Ind Farmers Digest 25(11): 21-23, 1992

Patel, S. M., B. K. Patel. 1998. Inhibitory effect of different fungal bio-agents on Fusarium oxysporum f. sp. Cumini causing cumin wilt. Annals of Plant Protection Science 6(1): 25-27.

Postma, J., M. Montanari and J. F. Van den Boogert (2003). Microbial enrichment to enhance disease suppressive activity of compost. European Journal of Soil Biology. 39:157-163.

\section{How to cite this article:}

Sabiya Bashir, Mohammad Najeeb Mughal, Seeratun Nissa, Zahoor A. Dar, S.A. Hakeem, Shabeena Majeed, Shaheena Nagoo and Sabeena Naseer. 2018. Efficacy of Some Fungicides and Bio-control Agents against Tuber Rot (Fusarium oxysporum) of Kalazeera (Bunium persicum). Int.J.Curr.Microbiol.App.Sci. 7(07): 3752-3757. doi: https://doi.org/10.20546/ijcmas.2018.707.434 